\title{
The Isochronic Component of Pointing Movement in Children Aged from 26 to 40 Months.
}

\author{
N. Bonneton and D. Mellier
}

\section{(2) OpenEdition}

1 Journals

Electronic version

URL: http://journals.openedition.org/cpl/196

DOI: $10.4000 / \mathrm{cpl} .196$

ISSN: $1379-6100$

Publisher

Centre PsyCLÉ

Printed version

Date of publication: 1 December 2001

\section{Electronic reference}

N. Bonneton and D. Mellier, « The Isochronic Component of Pointing Movement in Children Aged from 26 to 40 Months. ", Current psychology letters [Online], 2001/3, 6 | 2001, Online since 05 September 2003, connection on 08 September 2020. URL : http://journals.openedition.org/cpl/196 ; DOI : https:// doi.org/10.4000/cpl.196

This text was automatically generated on 8 September 2020

(C) All rights reserved 
The Isochronic Component of Pointing Movement in Children Aged from 26 to 40 Months.

N. Bonneton and D. Mellier 